\title{
Studi Analisis Governor sebagai Load Frequency Control pada PLTG menggunakan Fuzzy Logic Controller
}

\author{
Gusti Made Ngurah Christy Aryanata ${ }^{1}$, I Nengah Suweden ${ }^{2}$, I Made Mataram ${ }^{3}$
}

\begin{abstract}
A good electrical power system is a system that can serve the load in a sustainable and stable voltage and frequency. Changes in frequency occur due to the demand of loads that change from time to time. The frequency setting of the PLTG power system depends on the active power charge in the system. This active power setting is done by adjusting the magnitude of the generator drive coupling. The frequency setting is done by increasing and decreasing the amount of primary energy (fuel) and carried on the governor. Simulation in governor analysis study as load frequency control at PLTG using fuzzy logic controller is done by giving four types of cultivation that is $0,1 \mathrm{pu}, 0,2 \mathrm{pu}, 0,3 \mathrm{pu}$ and $0,4 \mathrm{pu}$. The simulation is done to compare the dynamic frequency response output and the resulting stability time using fuzzy logic controller with PI controller. Based on the results of comparative analysis conducted to prove that governor as load frequency control using fuzzy logic control is better than using PI controller. This can be seen from the output response frequency and time stability.
\end{abstract}

Intisari- Sistem tenaga listrik yang baik merupakan suatu sistem yang dapat melayani beban secara berkelanjutan serta tegangan dan frekuensinya stabil. Perubahan frekuensi terjadi disebabkan oleh permintaan beban yang berubah-ubah dari waktu ke waktu. Pengaturan frekuensi pada sistem pambangkit PLTG tergantung pada pengisisan daya aktif dalam sistem. Pengaturan daya aktif ini dilakukan dengan mengatur besarnya kopel penggerak generator. Pengaturan frekuensi dilakukan dengan menambah dan mengurangi jumlah energi primer (bahan bakar) dan dilakukan pada governor. Simulasi dalam studi analisis governor sebagai load frequency control pada PLTG menggunakan fuzzy logic controller dilakukan dengan memberikan empat jenis pembebaban yaitu sebesar $0,1 \mathrm{pu}$, 0,2pu, 0,3 pu dan 0,4 pu. Simulasi dilakukan untuk membandingkan output respon frekuensi dinamik dan waktu kestabilan yang dihasilkan menggunakan fuzzy logic controller dengan PI controller. Berdasarkan hasil analisis perbandingan yang dilakukan membuktikan bahwa governor sebagai load frequency control menggunakan fuzzy logic control lebih baik dibandingkan dengan menggunakan PI kontroller. Hal ini dapat dilihat dari output respon frekuensi dan waktu kestabilannya.

Kata Kunci : Governor, Load Frequency Control, PLTG, Fuzzy Logic Controller

${ }^{1}$ Mahasiswa, Program Studi Teknik Elektro Fakultas Teknik Universitas Udayana, Br. Tegal Buah, Padang Sambian, Denpasar Barat, Denpasar, Bali, Indonesia (telp: 081239363730; e-mail: caryanata@gmail.com)

${ }^{2}$ Dosen, Program Studi Teknik Elektro Fakultas Teknik Universitas Udayana, Jl. Batas Dukuh Sari, Gang Curik no. 3, Pedungan, Denpasar Bali, Indonesia (telp: 081558803160; e-mail: suweden@ee.unud.ac.id)

${ }^{3}$ Dosen Program Studi Teknik Elektro Fakultas Teknik Universitas Udayana, Jl. Gajah Waktra Taman Wahana Asri Kavling Baru no. 1, Peguuyangan Kaja, Denpasar, Indonesia (telp: 085100419479; e-mail: mataram@unud.ac.id)

Gusti Made Ngurah Christy Aryanata: Studi Analisis Governor sebagai...

\section{PENDAHULUAN}

Sistem tenaga listrik yang baik merupakan suatu sistem yang dapat melayani permintaan beban secara berkelanjutan serta tegangan dan frekuensinya stabil. Kondisi sistem yang stabil sebenarnya tidak pernah ada. Adanya perubahan permintaan beban listrik pasti terjadi dalam sistem. Permintaan beban listrik yang selalu berubah dari waktu ke waktu dapat menyebabkan frekuensi listrik menjadi tidak stabil [1].

Pengaturan frekuensi listrik dilakukan di governor dengan cara mengatur jumlah bahan yang masuk ke ruang pembakaran (combuster) yang menerima sinyal dari perubahan frekuensi listrik. Bila beban listrik naik maka frekuensi akan turun, sehingga governor harus memperbesar masukan bahan bakar ke mesin penggerak utama untuk menaikan frekuensinya sampai dengan frekuensi listrik kembali ke batas standar yang diijinkan yaitu $50 \mathrm{~Hz} \pm 2 \%$ [2]. Begitu juga sebaliknya bila beban listrik turun maka frekuensi akan naik, governor mesin-mesin pembangkit harus mengurangi masukan bahan bakar ke mesin penggerak utama untuk menurunkan frekuensinya sampai dengan frekuensi listrik kembali ke batas standar yang diijinkan.

Saat ini berbagai usaha dan metode telah digunakan oleh para ahli untuk menjaga kestabilan khususnya terkait dengan masalah perubahan frekuensi. Berbagai usaha ini dimulai dari desain kontroler metode konvensional dalam load frequency control. Penggunaan metode konvensional pada load frequency control dapat menambah kontoler P (proposional), I (integral), dan D (derivactive) dalam sistem. Berkembangnya pemodelan modern terdapat metode kecerdasan buatan atau Artificial Intelegence (AI), metode ini meliputi fuzzy logic, neural network, genetic algorithm, dan lain sebagainya [3]. Metode yang akan digunakan penulis pada penelitian ini adalah fuzzy logic controller. Pada penelitian ini, penulis akan membandingkan governor sebagai load frequency control pada PLTG menggunakan fuzzy logic controller dengan PI kontroller untuk mengetahui output respon frekuensi yang lebih baik dan error steady state yang lebih kecil serta waktu kestabilan yang lebih cepat diantara kedua metode tersebut.

\section{STUDI LITERATUR}

A. Governor

Governor merupakan peralatan mekanis yang digunakan sebagai 'interface' antara turbin penggerak dan generator. Pengaturan putaran turbin sejak turbin mulai bergerak sampai steady state dilakukan oleh governor, jadi bukan diambil alih oleh governor. Fungsi utama pengaturan putaran ini adalah untuk menjaga kestabilan sistem secara keseluruhan terhadap adanya variasi beban atau gangguan pada sistem [4].

\section{B. Sistem Pengendalian Daya Aktif dan Frekuensi}


Daya aktif mempunyai hubungan erat dengan nilai frekuensi dalam suatu sistem, sedangkan beban sistem yang berupa daya aktif selalu berubah dari waktu ke waktu. Sehubungan dengan hal ini, maka untuk mempertahankan frekuensi dalam batas toleransi yang diijinkan, penyediaan daya aktif dalam sistem harus sesuai dengan beban daya aktif. Pengaturan penyesuaian daya aktif ini dilakukan dengan cara mengatur besarnya kopel penggerak generator [5].

Pengaturan daya aktif dilakukan oleh LFC (Load Frequency Control) seperti yang terlihat pada gambar 1 .

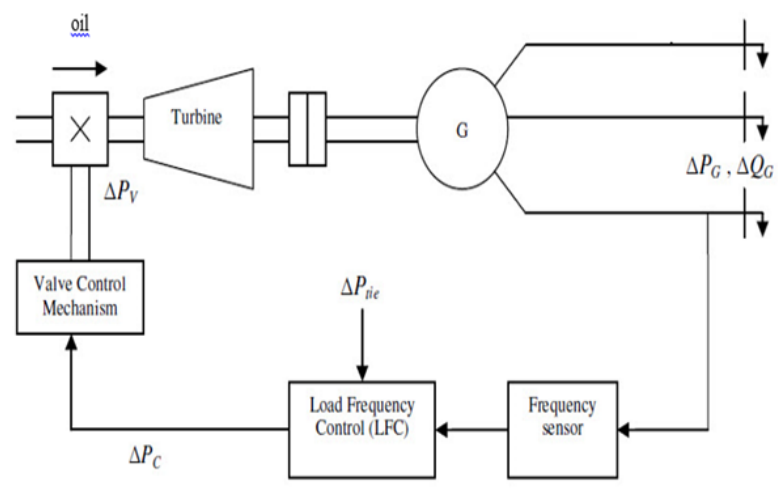

Gambar 1: Diagram blok load frequency control [5]

Frekuensi merupakan faktor umum yang terdapat pada seluruh sistem, perubahan permintaan daya aktif akan menyebabkan perubahan pada frekuensi. Oleh karena itu terdapat banyak generator mensuplai daya ke sistem. Maka pada pembangkit harus disediakan alokasi perubahan pada permintaan terhadap generator. Kecepatan governor pada tiap pembangkit memberikan kecepatan pokok sebagai fungsi pengaturan.

\section{Model Generator}

Generator merupakan instrument pembangkitan tenaga listrik yang mengubah energi mekanis sebagai input menjadi energi listrik sebagai output. Generator terdiri dari dua bagian yaitu bagian yang berputar yang disebut dengan rotor dan bagian yang diam disebut dengan stator [5]. Gambar pemodelan generator dapat dilihat pada gambar 2 .

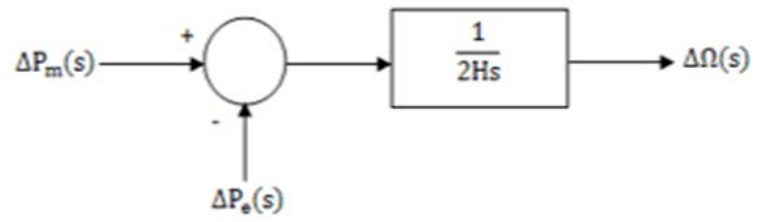

Gambar 2: Diagram blok model generator [5]

Persamaan transfer function untuk blok diagram generator di atas adalah.

$$
\frac{2 H}{\omega_{s}} \frac{\partial^{2} \Delta \delta}{\partial t}=\Delta P_{m}-\Delta P_{e}
$$

Dalam keadaan penyimpangan (deviasi) kecepatan kecil

$$
\frac{\partial \Delta \frac{\omega}{\omega_{S}}}{\partial t}=\frac{1}{2 H}\left(\Delta P_{m}-\Delta P_{e}\right)
$$

Jika persamaan di atas ditransformasikan ke dalam persamaan laplace menjadi

$$
\Delta \Omega(s)=\frac{1}{2 H_{S}}\left[\Delta P_{m}(s)-\Delta P_{e}(s)\right]
$$

Keterangan :

$\Delta \Omega(\mathrm{s}) \quad=$ Perubahan kecepatan $(\mathrm{rad} / \mathrm{s})$

$\mathrm{H} \quad=$ Konstanta inersia

$\Delta \mathrm{P}_{\mathrm{m}}(\mathrm{s})=$ Perubahan daya mekanik (Watt)

$\Delta \mathrm{P}_{\mathrm{e}}(\mathrm{s}) \quad=$ Perubahan daya akibat perubahan beban (Watt)

\section{Model Beban}

Beban pada sistem tenaga listrik terdiri dari gabungan peralatan listrik yang dipasang pada sistem. Untuk beban resistif, seperti pencahayaan dan beban pemanasan, daya listrik tidak bergantung pada frekuensi. Dalam kasus beban motor daya listrik sangat tergantung pada perubahan frekuensi [5].

Komponen $\Delta \mathrm{P}_{\mathrm{e}}(\mathrm{s})$ merupakan penjumlahan antara komponen frekuensi sensitive (D $\Delta \omega$ ) dan non-frekuensi sensitive $\left(\Delta \mathrm{P}_{\mathrm{L}}\right)$, seperti pada persamaan berikut ini.

$$
\Delta \mathrm{P}_{\mathrm{e}}=\Delta \mathrm{P}_{\mathrm{L}}+\mathrm{D} \Delta \omega
$$

Keterangan :

$\Delta \mathrm{P}_{\mathrm{e}} \quad$ : Perubahan nonfrequency-sensitive load

$\mathrm{D} \Delta \omega$ : Perubahan frequency-sensitive load

D : Konstanta redaman beban

Blok diagram beban dari persamaan diatas dapat dilihat pada gambar 3 .

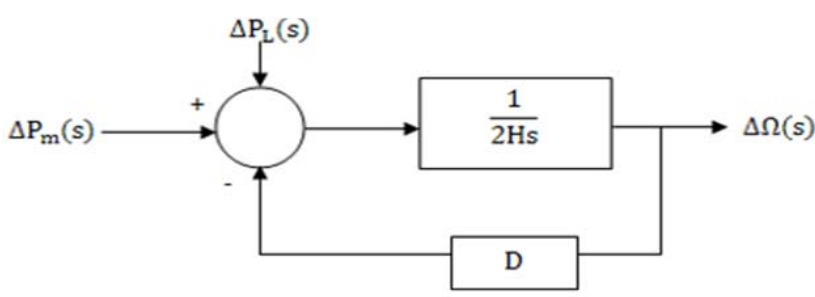

Gambar 3: Diagram blok beban (load) [5]

$\Delta \mathrm{P}_{\mathrm{m}}$ adalah daya mekanis yang disebabkan karena adanya perputaran turbin, $\Delta \mathrm{P}_{\mathrm{e}}$ merupakan daya elektris yang dihasilkan oleh adanya perubahan beban. Sedangkan D (redaman) merupakan perubahan beban yang mempengaruhi perubahan frekuensi [5]. Diagram blok beban (load) dapat juga disederhanakan dalam bentuk gain dan time constant dalam bentuk persamaan sebagai berikut.

$$
\begin{aligned}
K & =\frac{1}{D} \operatorname{dan} T \frac{M}{f(D)} \\
M & =2 H
\end{aligned}
$$

Keterangan :

$$
\begin{array}{ll}
\mathrm{K} & =\text { Power system gain }(\mathrm{Hz} / \mathrm{pu} \mathrm{MW}) \\
\mathrm{T} & =\text { Area equivalent generating unit time constant (sec) } \\
\mathrm{H} & =\text { Inertia constant (sec) }
\end{array}
$$

E. Model Penggerak Mula 
Pemodelan penggerak mula atau yang dimaksud dalam hal ini adalah turbin gas adalah melihat adanya hubungan antara daya mekanik $\Delta P_{m}$ dan perubahan posisi dari katup (valve) $\Delta P_{V}$ [5]. Model matematis turbin dapat dituliskan dalam persamaan sebagai berikut.

$$
\mathrm{G}_{\mathrm{T}}(\mathrm{s})=\frac{\Delta \mathrm{P}_{\mathrm{m}}(\mathrm{s})}{\Delta \mathrm{P}_{\mathrm{v}}(\mathrm{s})}=\frac{1}{1+\tau T_{\mathrm{s}}}
$$

Blok diagram penggerak mula dengan persamaan di atas dapat dilihat pada gambar 4 .

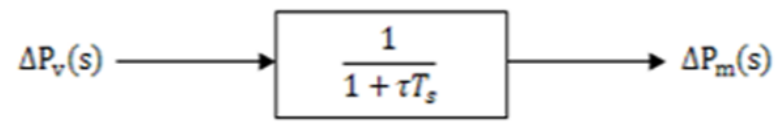

Gambar 4: Diagram blok penggerak mula [5]

\section{F. Model Governor}

Model matematis untuk suatu governor dapat dituliskan sebagai berikut :

$$
\Delta P_{g}(\mathrm{~s})=\Delta P_{\text {reff }}(\mathrm{s})-\frac{1}{R} \Delta \Omega(\mathrm{s})
$$

Keterangan :

$\Delta P_{g} \quad$ : Daya output governor (Watt)

$\Delta P_{\text {reff }}:$ Daya referensi/acuan (Watt)

$\mathrm{R} \quad$ : Speed regulation (berkisar $5-6$ persen)

$\Delta \Omega(\mathrm{s}) \quad$ : Perubahan kecepatan $(\mathrm{rad} / \mathrm{s})$

Daya output governor $\Delta P_{g}$ tersebut diubah dari penguat hidraulik ke sinyal input posisi katup (valve) $\Delta P_{V}$, sehingga hubungan antara keduanya menjadi persamaan berikut [6]:

$$
\Delta P_{v}(\mathrm{~s})=\frac{1}{1+\tau g} \Delta P_{g}(\mathrm{~s})
$$

Persamaan di atas dengan $\tau g$ merupakan konstanta waktu governor. Sehingga persamaan (7) dan (8) dapat digambarkan dalam bentuk diagram blok pada gambar 5 .

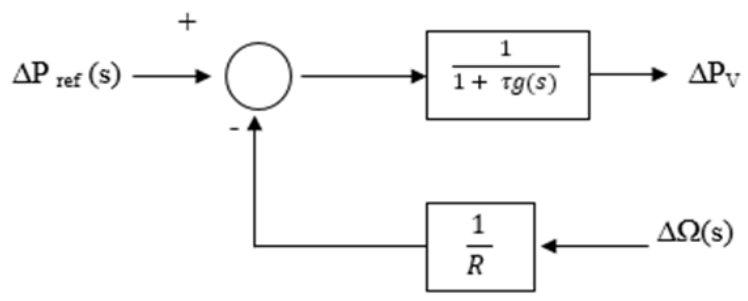

Gambar 5: Diagram blok model governor [6]

Menurut hukum Newton ada hubungan antara Kopel mekanis penggerak generator dengan perputaran generator [6], yaitu:

$$
\left(T_{G}-T_{B}\right)=H \times \frac{d \omega}{d t}
$$

Keterangan :

$\mathrm{T}_{\mathrm{G}} \quad=$ Kopel penggerak Generator
$\mathrm{T}_{\mathrm{B}}=$ Kopel Beban yang membebani Generator

$\mathrm{H} \quad=$ Momen Inersia

$\omega \quad=$ Kecepatan Sudut perputaran Generator

$T_{G}-T_{B}=\Delta \mathrm{T}<0$, maka $\frac{d \omega}{d t}<0$, frekuensi turun

$T_{G}-T_{B}=\Delta \mathrm{T}>0$, maka $\frac{d \omega}{d t}>0$, frekuensi naik

Secara tidak langsung penyediaan daya reaktif dapat juga mempengaruhi frekuensi sistem, karena penyediaan daya reaktif mempunyai pengaruh besar terhadap kenaikan tegangan yang kemudian dapat menyebabkan kenaikan dari beban daya aktif [7].

G. Fuzzy Logic

Logika Fuzzy (Fuzzy Logic) merupakan metode pemecahan masalah menggunakan operasi aturan dasar (rule base) yang dapat memproses sejumlah input dan output yang masuk akal pada sistem nonlinear dan sistem yang kompleks [8].

Cara kerja fuzzy logic terdiri dari empat proses. Proses tersebut adalah sebagai berikut

1) Fuzzyfikasi merupakan suatu proses pengubahan nilai tegas atau real ke dalam fungsi keanggotaan [9].

2) Penalaran (Interfrence Machine) merupakan proses implikasi penalaran nilai input guna menetukan nilai output sebagai bentuk pengambilan keputusan. Salah satu model penalaran yang biasa digunakan adalah metode mamdani (min-max) [9].

3) Aturan dasar (Rule Base) merupakan suatu bentuk aturan relasi atau implikasi "If-Then" seperti pada pernyataan berikut ini: "If" $\mathrm{X}=\mathrm{A}$ and "If" $\mathrm{Y}=\mathrm{B}$ "Then" $\mathrm{Z}=\mathrm{C}$ [9].

4) Defuzzifikasi merupakan proses pemetaan himpunan fuzzy ke himpunan tegas (crisp). Proses ini adalah kebalikan dari proses fuzzyfikasi [9].

Proses dalam fuzzy inference system dapat digambarkan seperti pada gambar 6 .

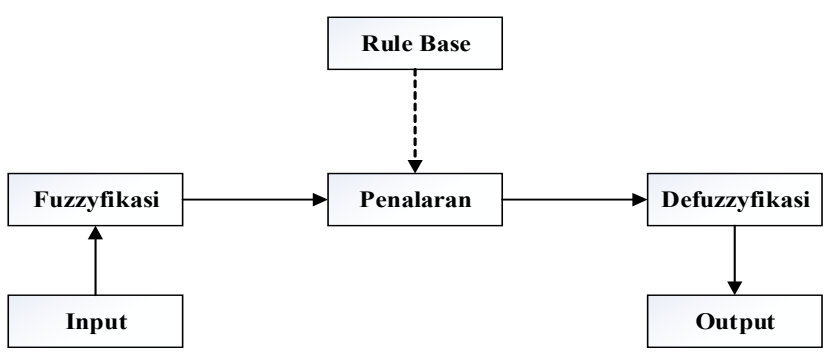

Gambar 6: Proses fuzzy inference system [9]

\section{METODE PENELITIAN}

Penelitian ini dilakukan di Jurusan Teknik Elektro Fakultas Teknik Universitas Udayana Kampus Sudirman Denpasar, Proses penelitian ini dilakukan mulai bulan Mei tahun 2016. Adapun data yang digunakan diperoleh dari paper oleh Yao Zhang yang berjudul Load Frequency Control of Multiple-Area Power System [10]. Data-data yang diperlukan untuk penelitian ini dapat dilihat pada Tabel I sebagai berikut.

Gusti Made Ngurah Christy Aryanata: Studi Analisis Governor sebagai... 
TABEL I

PARAMETER VARIABEL NILAI INPUT

\begin{tabular}{lll}
\hline No. & Spesifikasi & Nilai \\
1 & Frekuensi bias area $\left(B_{1}\right)$ & $0.3483 \mathrm{pu} / \mathrm{Hz}$ \\
2 & Frekuensi bias area $\left(B_{2}\right)$ & $0.3473 \mathrm{pu} / \mathrm{Hz}$ \\
3 & Governor time constant $\left(\mathrm{\tau g}_{1}\right)$ & $0.08 \mathrm{sec}$ \\
4 & Governor time constant $\left(\mathrm{g}_{2}\right)$ & $0.06 \mathrm{sec}$ \\
5 & Turbine time constant $\left(\tau \mathrm{t}_{1}\right)$ & $0.4 \mathrm{sec}$ \\
6 & Turbine time constant $\left(\tau \mathrm{g}_{2}\right)$ & $0.36 \mathrm{sec}$ \\
7 & Speed Regulation & 0.05 \\
8 & Damping $\left(D_{1}\right)$ & $0.0150 \mathrm{pu} / \mathrm{Hz}$ \\
9 & Damping $\left(D_{2}\right)$ & $0.0140 \mathrm{pu} / \mathrm{Hz}$ \\
10 & Konstanta inersia & 0.1667 \\
11 & Konstanta inersia & 0.1200 \\
12 & Synchronizing coefficient $\left(T_{12}\right)$ & $0.2 \mathrm{pu} / \mathrm{rad}$ \\
13 & Frekuensi $(f)$ & $50 \mathrm{~Hz}$ \\
14 & P Load Change & $0.1 \mathrm{pu}, 0.2 \mathrm{pu}, 0.3 \mathrm{pu}, 0.4 \mathrm{pu}$ \\
\hline
\end{tabular}

Data yang ada pada tabel I kemudian dianalisis dengan prosedur yaitu membuat blok diagram dan pemodelan governor sebagai load frequency control. Pemodelan dibuat dalam bentuk sistem tenaga listrik 2 area. Simulasi dilakukan dengan bantuan perangkat lunak yaitu Matlab, dimana simulasi dilakukan menggunakan dua metode yaitu simulasi menggunakan fuzzy logic controller metode mamdani dengan lima membership function dan metode PI kontroller. Kemudian kedua hasil simulasi tersebut dibandingkan untuk mengetahui output respon frekuensi yang lebih baik dan error steady state yang lebih kecil serta waktu kestabilan yang lebih cepat. Alur analisis dapat dilihat pada Gambar 7.

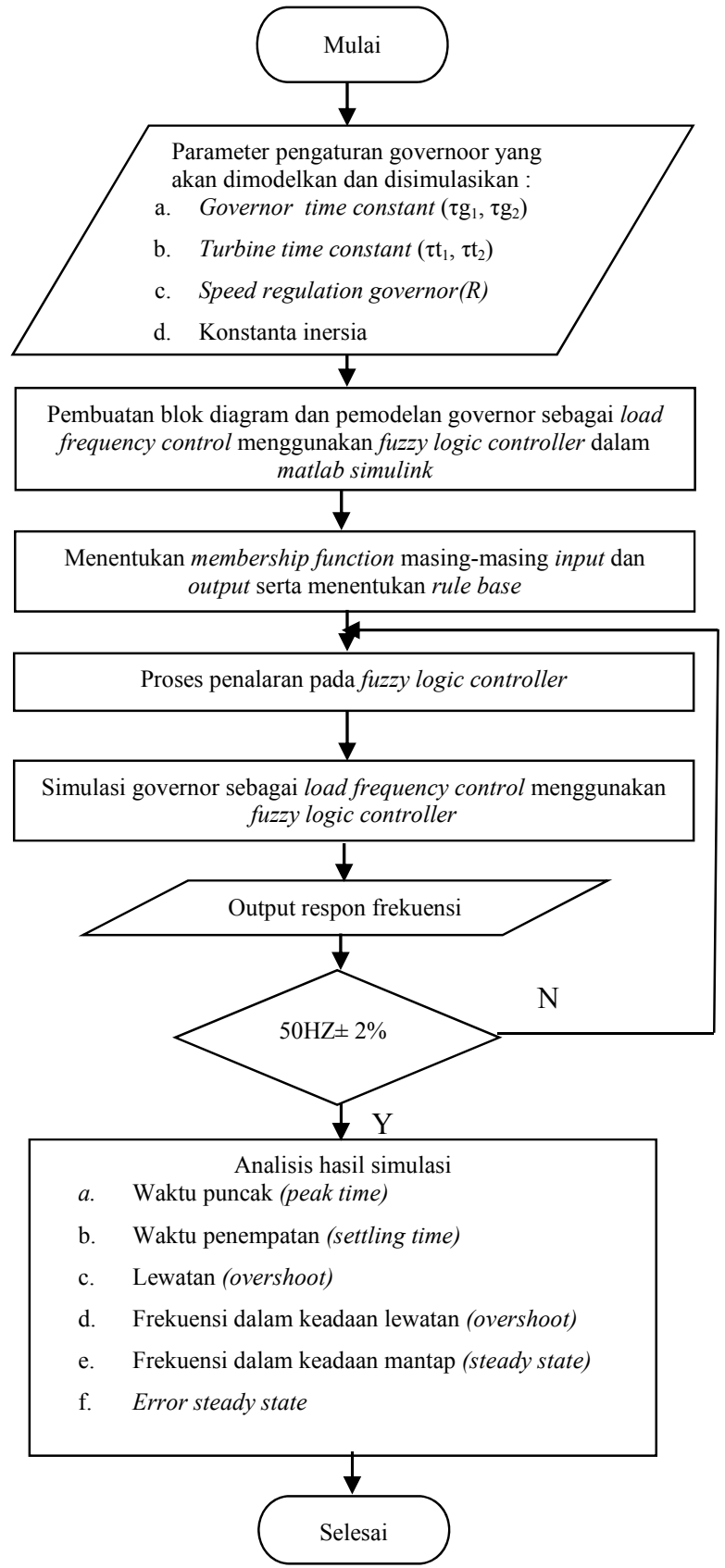

Gambar 7: Alur analisis

\section{HASIL DAN PEMBAHASAN}

A. Pemodelan dan simulasi Governor sebagai Load Frequency Control menggunakan Metode PI Kontroller

Pemodelan dan simulasi governor sebagai load frequency control menggunakan metode PI Kontroller dilakukan dengan bantuan perangkat lunak (software) Matlab. Pada gambar 8 merupakan pemodelan sistem yang sudah dimasukan parameter variabel nilai input yang telah tersedia pada tabel I dan pada area 1 diberikan beban listrik sebesar $0.1 \mathrm{pu}, 0.2 \mathrm{pu}$ $0.3 \mathrm{pu}$ dan $0.4 \mathrm{pu}$ pada selang waktu 2 detik dari waktu referensi. 


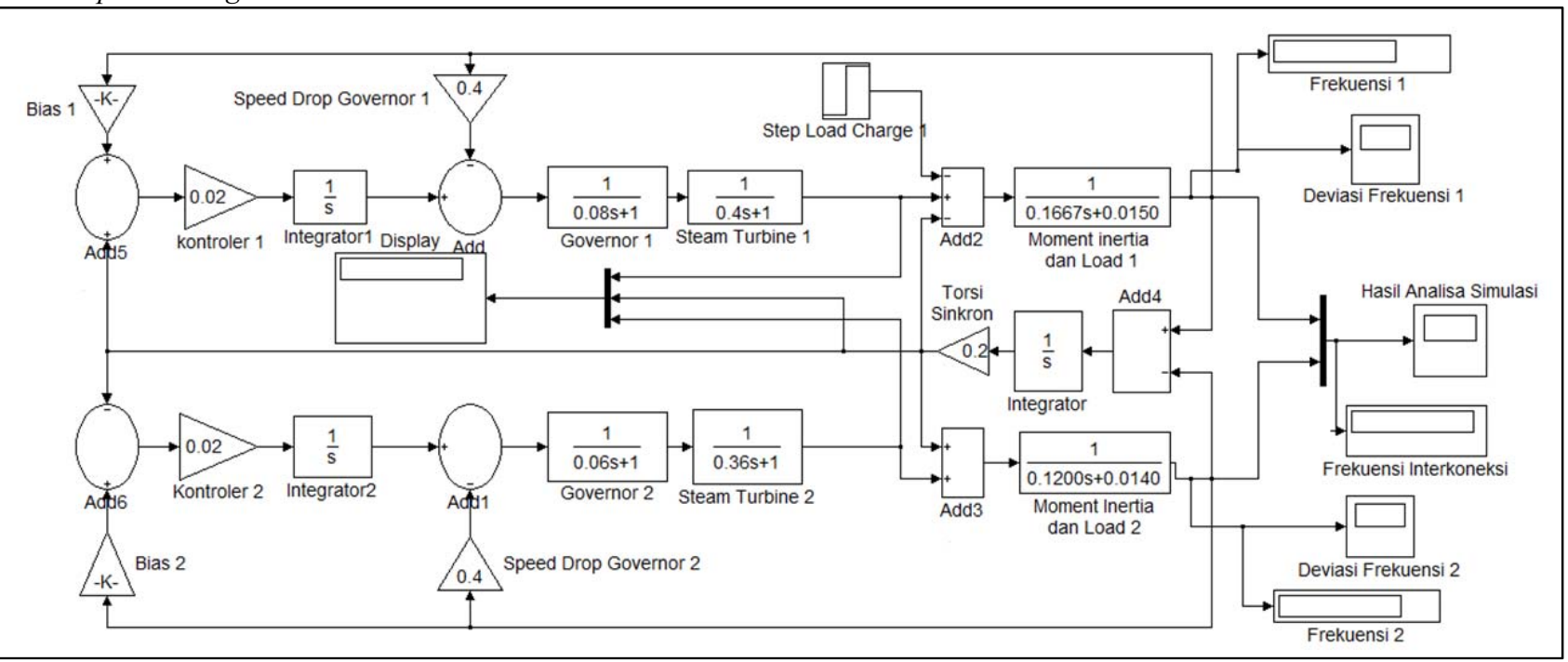

Gambar 8: Pemodelan governor sebagai load frequency control menggunaka metode PI kontroller

Tampilan hasil simulasi governor sebagai load frequency control menggunakan PI kontroller pada area 1 dan area 2 yang dilakukan pada gambar 8 dapat dilihat pada gambar 9 dan 10.

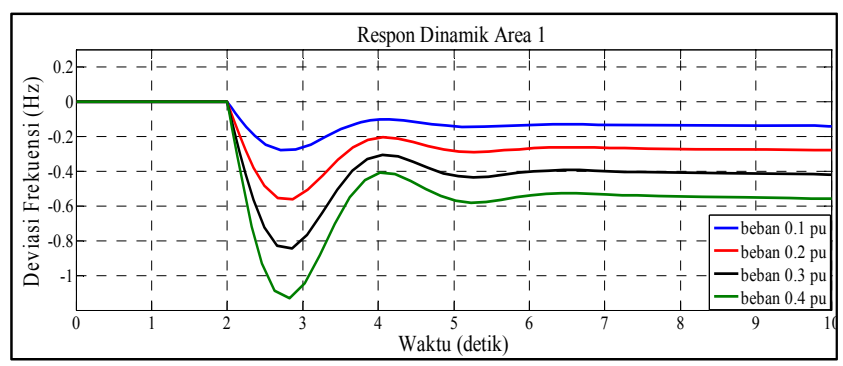

Gambar 9: Hasil simulasi load frequency control pada Area 1

Berdasarkan hasil simulasi yang ditampilkan pada gambar 9 diperoleh hasil respon dinamik sebagai berikut:

TABEL II

HASIL RESPON DINAMIK LOAD FREQUENCY CONTROL AREA 1

\begin{tabular}{lcccc}
\hline & $\mathbf{0 . 1} \mathbf{~ p u}$ & $\mathbf{0 . 2} \mathbf{~ p u}$ & $\mathbf{0 . 3} \mathbf{~ p u}$ & $\mathbf{0 . 4} \mathbf{~ p u}$ \\
\hline Peak time (Tp) & 2.7 detik & 2.8 detik & 2.8 detik & 2.8 detik \\
$\begin{array}{l}\text { Settling time (Ts) } \\
\text { Deviasi frekuensi } \\
\text { overshoot }\end{array}$ & 8.5 detik & 8.5 detik & 8.5 detik & 8.5 detik \\
$\begin{array}{l}\text { Deviasi frekuensi } \\
\text { steady state }\end{array}$ & $-0.28 \mathrm{~Hz}$ & $-0.56 \mathrm{~Hz}$ & $-0.84 \mathrm{~Hz}$ & $-1.13 \mathrm{~Hz}$ \\
Frekuensi overshoot & $49.72 \mathrm{~Hz}$ & $49.44 \mathrm{~Hz}$ & $49.16 \mathrm{~Hz}$ & $48.87 \mathrm{~Hz}$ \\
Frekuensi steady state & $49.86 \mathrm{~Hz}$ & $49.73 \mathrm{~Hz}$ & $49.59 \mathrm{~Hz}$ & $49.43 \mathrm{~Hz}$ \\
\%error steady state & $0.28 \%$ & $0.54 \%$ & $0.82 \%$ & $1.1 \%$ \\
\hline
\end{tabular}

Gusti Made Ngurah Christy Aryanata: Studi Analisis Governor sebagai...

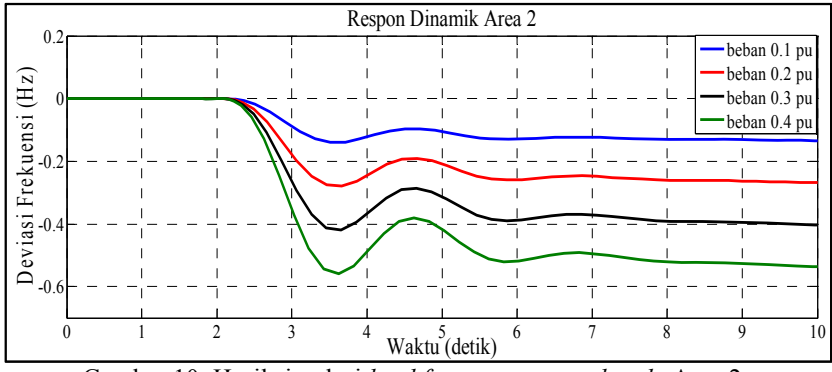

Gambar 10: Hasil simulasi load frequency control pada Area 2

Berdasarkan hasil simulas yang ditampilkan pada gambar 10 diperoleh hasil respon dinamik sebagai berikut:

TABEL III

HASIL RESPON DINAMIK LOAD FREQUENCY CONTROL AREA 2

\begin{tabular}{|c|c|c|c|c|}
\hline & $0.1 \mathrm{pu}$ & $0.2 \mathrm{pu}$ & $0.3 \mathrm{pu}$ & $0.4 \mathrm{pu}$ \\
\hline Peak time (Tp) & 3.5 detik & 3.6 detik & 3.6 detik & 3.6 detik \\
\hline Settling time (Ts) & 9 detik & 9 detik & 9 detik & 9 detik \\
\hline $\begin{array}{l}\text { Deviasi frekuensi } \\
\text { overshoot }\end{array}$ & $-0.13 \mathrm{~Hz}$ & $-0.27 \mathrm{~Hz}$ & $-0.41 \mathrm{~Hz}$ & $-0.56 \mathrm{~Hz}$ \\
\hline $\begin{array}{l}\text { Deviasi frekuensi } \\
\text { steady state }\end{array}$ & $-0.14 \mathrm{~Hz}$ & $-0.27 \mathrm{~Hz}$ & $-0.41 \mathrm{~Hz}$ & $-0.55 \mathrm{~Hz}$ \\
\hline Frekuensi overshoot & $49.87 \mathrm{~Hz}$ & $49.73 \mathrm{~Hz}$ & $49.59 \mathrm{~Hz}$ & $49.44 \mathrm{~Hz}$ \\
\hline Frekuensi steady state & $49.86 \mathrm{~Hz}$ & $49.73 \mathrm{~Hz}$ & $49.59 \mathrm{~Hz}$ & $49.45 \mathrm{~Hz}$ \\
\hline \%error steady state & $0.28 \%$ & $0.54 \%$ & $0.82 \%$ & $1.1 \%$ \\
\hline
\end{tabular}

Berdasarkan hasil respon dinamik load frequency control menggunakan PI kontroller pada tabel II dan tabel III menunjungkan sistem bekerja masih dalam range frekuensi yang diijinkan yaitu $49 \mathrm{~Hz}$ sampai dengan $51 \mathrm{~Hz}$. 
B. Pemodelan dan simulasi Governor sebagai Load Frequency Control menggunakan Fuzzy Logic Controller

Untuk dapat membuat pemodelan governor sebagai load frequency control menggunakan fuzzy logic controller, data yang diperlukan adalah area control error (ACE) sebagai input 1, deviasi area control error $(\triangle A C E)$ sebagai input 2 dan batas nilai frekuensi yang diijinkan sebagai output. Sehingga dengan data tersebut dapat disusun membership function serta rule base dari metode fuzzy logic. Pada penelitian ini menggunakan 5 membership function. Berikut adalah membership function masing-masing input dan output yang digunakan.

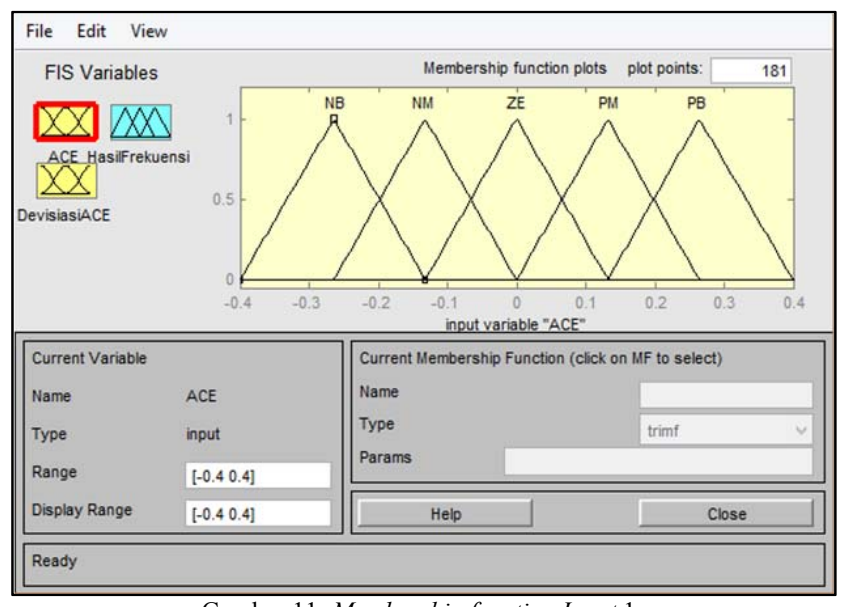

Gambar 11: Membership function Input 1

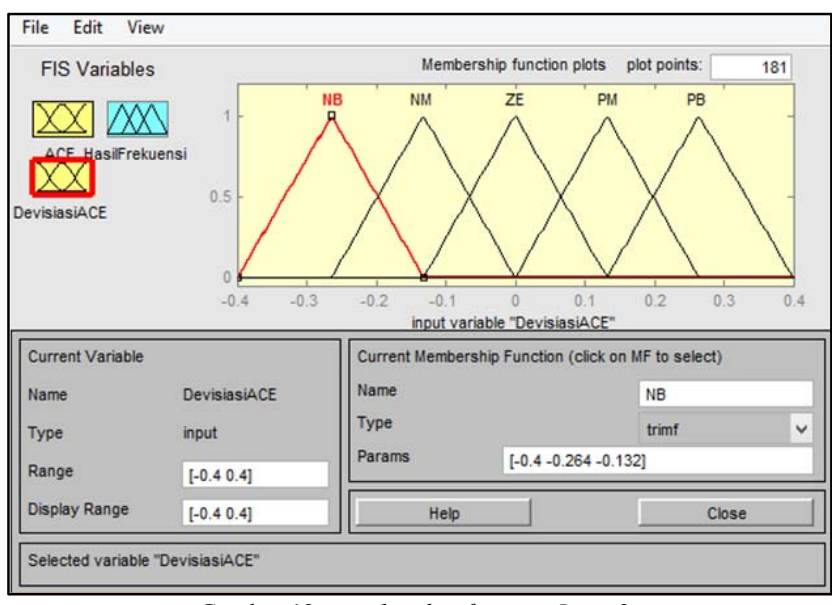

Gambar 12: membership function Input 2

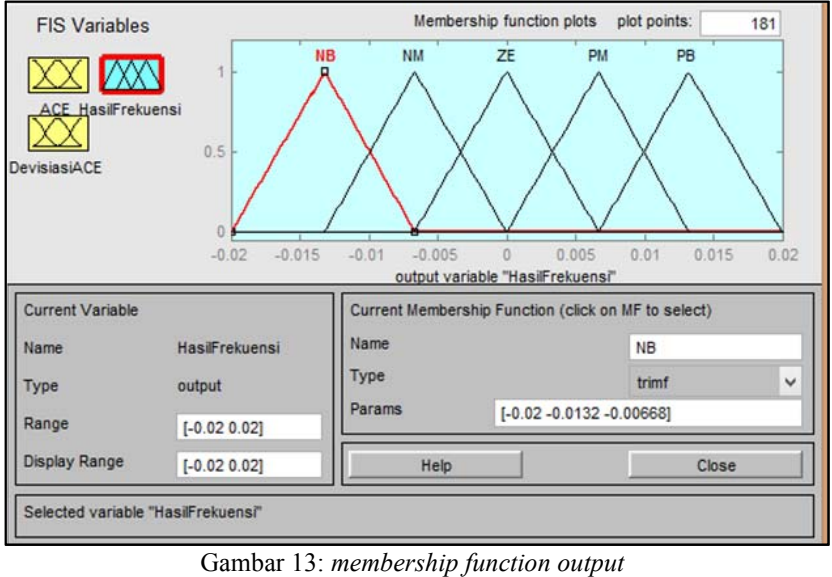

Setelah menentukan membership function tahap berikutnya adalah membuat rule base yang menampilkan hubungan antara input 1, input 2 dan output yang disebut interfancing. Hubungan antara membership function tersebut menghasilkan 25 rule base yang dapat dilihat pada Tabel IV

TABEL IV

RULE BASE GOVERNOR SEBAGAI LOAD FREQUENCY CONTROL MENGGUNAKAN FUZZY LOGIC CONTROLLER

\begin{tabular}{|l|c|c|c|c|c|}
\hline \multicolumn{1}{|c|}{ ACEE } & $\begin{array}{c}\text { Negative } \\
\text { Big (NB) }\end{array}$ & $\begin{array}{c}\text { Negative } \\
\text { Medium } \\
(\text { NM) }\end{array}$ & $\begin{array}{c}\text { Zero } \\
(\mathbf{Z E})\end{array}$ & $\begin{array}{c}\text { Positive } \\
\text { Medium } \\
(\boldsymbol{P M})\end{array}$ & $\begin{array}{c}\text { Positive } \\
\text { Big (PB) }\end{array}$ \\
\hline $\begin{array}{l}\text { Negative } \\
\text { Big (NB) }\end{array}$ & $N B$ & $N B$ & $N M$ & $N M$ & $Z E$ \\
\hline $\begin{array}{l}\text { Negative } \\
\text { Medium } \\
\text { (NM) }\end{array}$ & $N B$ & $N B$ & $N M$ & $Z E$ & $P M$ \\
\hline $\begin{array}{l}\text { Zero } \\
\text { (ZE) }\end{array}$ & $B M$ & $N M$ & $Z E$ & $P M$ & $P M$ \\
\hline $\begin{array}{l}\text { Positive } \\
\text { Medium } \\
\text { (PM) }\end{array}$ & $N M$ & $Z E$ & $P M$ & $P B$ & $P B$ \\
\hline $\begin{array}{l}\text { Positive } \\
\text { Big (PB) }\end{array}$ & $Z E$ & $P M$ & $P M$ & $P B$ & $P B$ \\
\hline
\end{tabular}

Setelah menentukan ke 25 rule base tahap berikutnya adalah membuat pemodelan governor sebagai load frequency control menggunakan fuzzy logic controller. Pemodelan tersebut dapat dilihat pada gambar 14 . 


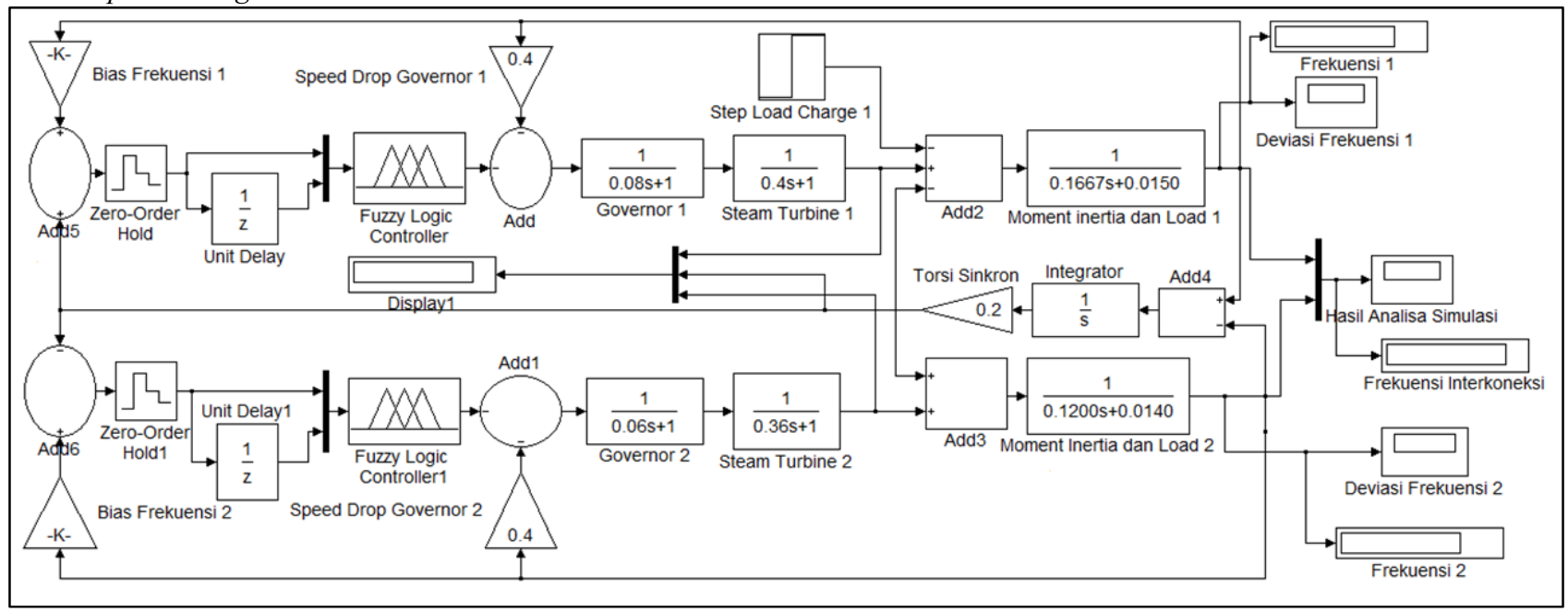

Gambar 14: Pemodelan governor sebagai load frequency control menggunakan fuzzy logic controller

Tampilan hasil simulasi respon dinamik load frequency control menggunakan fuzzy logic controller pada area 1 dan area 2 yang dilakukan pada gambar 14 dapat dilihat pada gambar 15 dan 16.

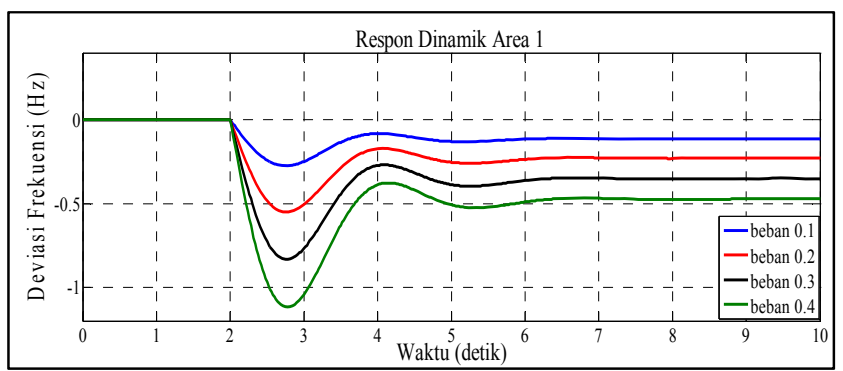

Gambar 15: Hasil simulasi load frequency control pada Area 1

Berdasarkan hasil simulasi yang ditampilkan pada gambar 15 diperoleh hasil respon dinamik sebagai berikut:

TABEL V HASIL RESPON DINAMIK LOAD FREQUENCY CONTROL AREA 1

\begin{tabular}{lcccc}
\hline & $\mathbf{0 . 1} \mathbf{~ p u}$ & $\mathbf{0 . 2} \mathbf{~ p u}$ & $\mathbf{0 . 3} \mathbf{~ p u}$ & $\mathbf{0 . 4} \mathbf{~ p u}$ \\
\hline Peak time (Tp) & $2.7 \mathrm{detik}$ & 2.7 detik & 2.7 detik & 2.7 detik \\
$\begin{array}{l}\text { Settling time (Ts) } \\
\begin{array}{l}\text { Deviasi frekuensi } \\
\text { overshoot }\end{array}\end{array}$ & $-0.9 \mathrm{detik}$ & $6 \mathrm{detik}$ & 6 detik & $6.1 \mathrm{detik}$ \\
$\begin{array}{l}\text { Deviasi frekuensi } \\
\text { steady state }\end{array}$ & $-0.11 \mathrm{~Hz}$ & $-0.22 \mathrm{~Hz}$ & $-0.34 \mathrm{~Hz}$ & $-0.47 \mathrm{~Hz}$ \\
$\begin{array}{l}\text { Frekuensi } \text { overshoot } \\
\text { Frekuensi steady state }\end{array}$ & $49.73 \mathrm{~Hz}$ & $49.45 \mathrm{~Hz}$ & $49.17 \mathrm{~Hz}$ & $48.89 \mathrm{~Hz}$ \\
\begin{tabular}{l} 
\%error steady state \\
\hline
\end{tabular} & $0.22 \%$ & $49.78 \mathrm{~Hz}$ & $49.66 \mathrm{~Hz}$ & $49.53 \mathrm{~Hz}$ \\
\hline
\end{tabular}

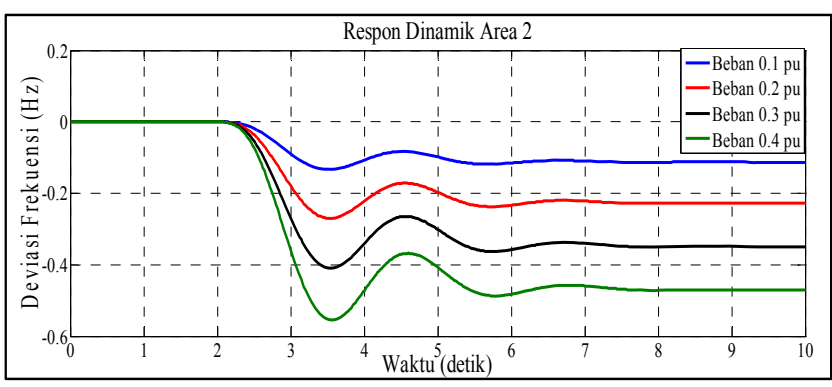

Gambar 16: Hasil simulasi load frequency control pada Area 2

Berdasarkan hasil simulasi yang ditampilkan pada gambar 16 diperoleh hasil respon dinamik sebagai berikut:

TABEL VI

HASIL RESPON DINAMIK LOAD FREQUENCY CONTROL AREA 2

\begin{tabular}{lcccc}
\hline & $\mathbf{0 . 1} \mathbf{~ p u}$ & $\mathbf{0 . 2} \mathbf{~ p u}$ & $\mathbf{0 . 3} \mathbf{~ p u}$ & $\mathbf{0 . 4} \mathbf{~ p u}$ \\
\hline Peak time (Tp) & $3.5 \mathrm{detik}$ & 3.5 detik & 3.5 detik & 3.5 detik \\
$\begin{array}{l}\text { Settling time (Ts) } \\
\begin{array}{l}\text { Deviasi frekuensi } \\
\text { overshoot }\end{array}\end{array}$ & $-0.1 \mathrm{detik}$ & $7.1 \mathrm{detik}$ & 7.1 detik & $7.1 \mathrm{detik}$ \\
$\begin{array}{l}\text { Deviasi frekuensi } \\
\text { steady state }\end{array}$ & $-0.11 \mathrm{~Hz}$ & $-0.22 \mathrm{~Hz}$ & $-0.34 \mathrm{~Hz}$ & $-0.47 \mathrm{~Hz}$ \\
$\begin{array}{l}\text { Frekuensi } \text { overshoot } \\
\begin{array}{l}\text { Frekuensi steady state } \\
\text { \%error steady state }\end{array}\end{array}$ & $49.87 \mathrm{~Hz}$ & $49.73 \mathrm{~Hz}$ & $49.60 \mathrm{~Hz}$ & $49.45 \mathrm{~Hz}$ \\
\hline
\end{tabular}

Berdasarkan hasil respon dinamik load frequency control menggunakan fuzzy logic controller pada tabel V dan tabel VI menunjungkan sistem bekerja masih dalam range frekuensi yang diijinkan yaitu $49 \mathrm{~Hz}$ sampai dengan $51 \mathrm{~Hz}$.

Gusti Made Ngurah Christy Aryanata: Studi Analisis Governor sebagai... 
C. Perbandingan Respon Dinamik Governor sebagai Load Frequency Control menggunakan Fuzzy Logic Control dengan PI Kontroller

Setelah dilakukan simulasi menggunakan metode PI Kontroller dan metode fuzzy logic controller, selanjutnya akan dibandingkan respon dinamik dari kedua metode tersebut. Perbandingan respon dinamik kedua metode tersebut akan ditampilkan berupa kurva dan tabel.

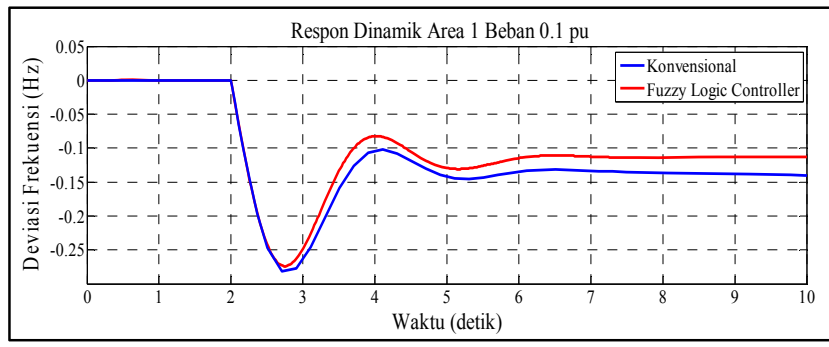

(a)

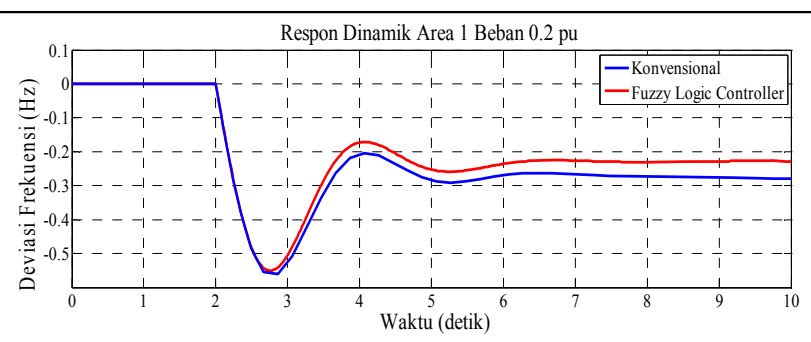

(b)

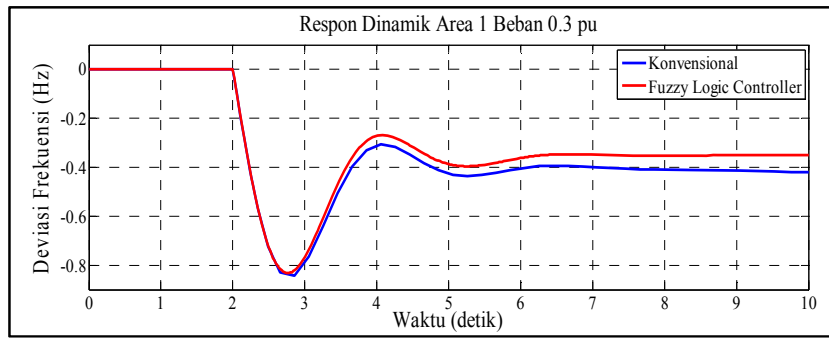

(c)

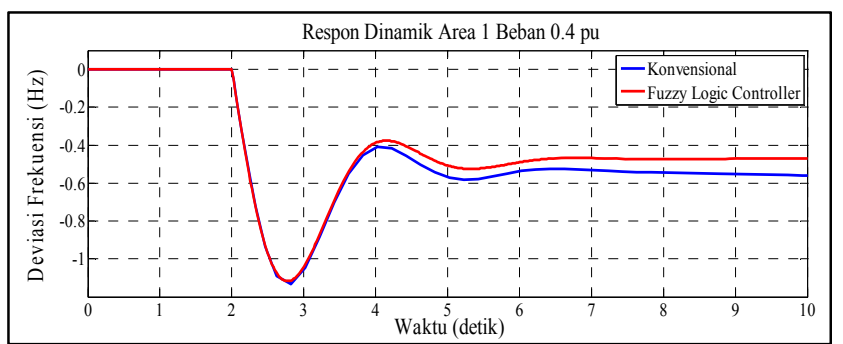

(d)

Gambar 17: Perbandingan hasil simulasi load frequency control area 1 dengan beban (a) $0.1 \mathrm{pu}$ (b) $0.2 \mathrm{pu}$ (c) $0.3 \mathrm{pu}$ (d) $0.4 \mathrm{pu}$

Berdarkan perbandingan hasil simulasi yang ditampilkan gambar 17 dapat diperoleh perbadingan respon dinamik load frequency control area 1 yang dapat dilihat pada Tabel VII.
TABEL VII

PERBANDINGAN RESPON DINAMIK LOAD FREQUENCY CONTROL PADA AREA 1

\begin{tabular}{|c|c|c|c|c|c|c|c|c|}
\hline & \multicolumn{2}{|c|}{$0.1 \mathrm{pu}$} & \multicolumn{2}{|c|}{$0.2 \mathrm{pu}$} & \multicolumn{2}{|c|}{$0.3 \mathrm{pu}$} & \multicolumn{2}{|c|}{$0.4 \mathrm{pu}$} \\
\hline & PI & FLC & PI & LFC & PI & LFC & PI & LFC \\
\hline $\begin{array}{l}\text { Peak time } \\
\quad(T p)\end{array}$ & $\begin{array}{c}2.7 \\
\text { detik }\end{array}$ & $\begin{array}{c}2.7 \\
\text { detik }\end{array}$ & $\begin{array}{c}2.8 \\
\text { detik }\end{array}$ & $\begin{array}{c}2.7 \\
\text { detik }\end{array}$ & $\begin{array}{c}2.8 \\
\text { detik }\end{array}$ & $\begin{array}{l}2.7 \\
\text { detik }\end{array}$ & $\begin{array}{l}2.8 \\
\text { detik }\end{array}$ & $\begin{array}{c}2.7 \\
\text { detik }\end{array}$ \\
\hline $\begin{array}{l}\text { Settling } \\
\text { time (Ts) }\end{array}$ & $\begin{array}{c}8.5 \\
\text { detik }\end{array}$ & $\begin{array}{c}5.9 \\
\text { detik }\end{array}$ & $\begin{array}{c}8.5 \\
\text { detik }\end{array}$ & $\begin{array}{c}6 \\
\text { Detik }\end{array}$ & $\begin{array}{c}8.5 \\
\text { detik }\end{array}$ & $\begin{array}{c}6 \\
\text { Detik }\end{array}$ & $\begin{array}{l}8.5 \\
\text { detik }\end{array}$ & $\begin{array}{c}6.1 \\
\text { detik }\end{array}$ \\
\hline $\begin{array}{c}\text { Deviasi } \\
\text { frekuensi } \\
\text { overshoot } \\
\text { Deviasi }\end{array}$ & $\begin{array}{c}-0.28 \\
\mathrm{~Hz}\end{array}$ & $\begin{array}{c}-0.27 \\
\mathrm{~Hz}\end{array}$ & $\begin{array}{c}-0.56 \\
\mathrm{~Hz}\end{array}$ & $\begin{array}{c}-0.55 \\
\mathrm{~Hz}\end{array}$ & $\begin{array}{c}-0.84 \\
\mathrm{~Hz}\end{array}$ & $\begin{array}{c}-0.83 \\
\mathrm{~Hz}\end{array}$ & $\begin{array}{c}-1.13 \\
\mathrm{~Hz}\end{array}$ & $\begin{array}{c}-1.11 \\
\mathrm{~Hz}\end{array}$ \\
\hline $\begin{array}{c}\text { frekuensi } \\
\text { steady } \\
\text { state }\end{array}$ & $\begin{array}{c}-0.14 \\
\mathrm{~Hz}\end{array}$ & $\begin{array}{c}-0.11 \\
\mathrm{~Hz}\end{array}$ & $\begin{array}{c}-0.27 \\
\mathrm{~Hz}\end{array}$ & $\begin{array}{c}-0.22 \\
\mathrm{~Hz}\end{array}$ & $\begin{array}{c}-0.41 \\
\mathrm{~Hz}\end{array}$ & $\begin{array}{c}-0.34 \\
\mathrm{~Hz}\end{array}$ & $\begin{array}{c}-0.55 \\
\mathrm{~Hz}\end{array}$ & $\begin{array}{c}-0.47 \\
\mathrm{~Hz}\end{array}$ \\
\hline $\begin{array}{l}\text { Frekuensi } \\
\text { overshoot }\end{array}$ & $\begin{array}{c}49.72 \\
\mathrm{~Hz}\end{array}$ & $\begin{array}{c}49.73 \\
\mathrm{~Hz}\end{array}$ & $\begin{array}{c}49.44 \\
\mathrm{~Hz}\end{array}$ & $\begin{array}{c}49.45 \\
\mathrm{~Hz}\end{array}$ & $\begin{array}{c}49.16 \\
\mathrm{~Hz}\end{array}$ & $\begin{array}{c}49.17 \\
\mathrm{~Hz}\end{array}$ & $\begin{array}{c}48.87 \\
\mathrm{~Hz}\end{array}$ & $\begin{array}{c}48.89 \\
\mathrm{~Hz}\end{array}$ \\
\hline $\begin{array}{c}\text { Frekuensi } \\
\text { steady } \\
\text { state }\end{array}$ & $\begin{array}{c}49.86 \\
\mathrm{~Hz}\end{array}$ & $\begin{array}{c}49.89 \\
\mathrm{~Hz}\end{array}$ & $\begin{array}{c}49.73 \\
\mathrm{~Hz}\end{array}$ & $\begin{array}{c}49.78 \\
\mathrm{~Hz}\end{array}$ & $\begin{array}{c}49.59 \\
\mathrm{~Hz}\end{array}$ & $\begin{array}{c}49.66 \\
\mathrm{~Hz}\end{array}$ & $\begin{array}{c}49.43 \\
\mathrm{~Hz}\end{array}$ & $\begin{array}{c}49.53 \\
\mathrm{~Hz}\end{array}$ \\
\hline $\begin{array}{c}\text { \%error } \\
\text { steady } \\
\text { state }\end{array}$ & $\begin{array}{c}0.28 \\
\%\end{array}$ & $\begin{array}{c}0.22 \\
\%\end{array}$ & $\begin{array}{c}0.54 \\
\%\end{array}$ & $\begin{array}{c}0.44 \\
\%\end{array}$ & $\begin{array}{c}0.82 \\
\%\end{array}$ & $\begin{array}{c}0.68 \\
\%\end{array}$ & $\begin{array}{l}1.1 \\
\%\end{array}$ & $\begin{array}{c}0.94 \\
\%\end{array}$ \\
\hline
\end{tabular}

Berdasarkan perbandingan yang ditunjukan pada Tabel VII dapat dilihat bahwa governor sebagai load frequency control menggunakan fuzzy logic controller menghasilkan output respon frekuensi yang lebih baik dan persentase error steady state yang lebih kecil serta waktu kestabilan yang lebih cepat dibandingkan menggunakan metode PI kontroller.

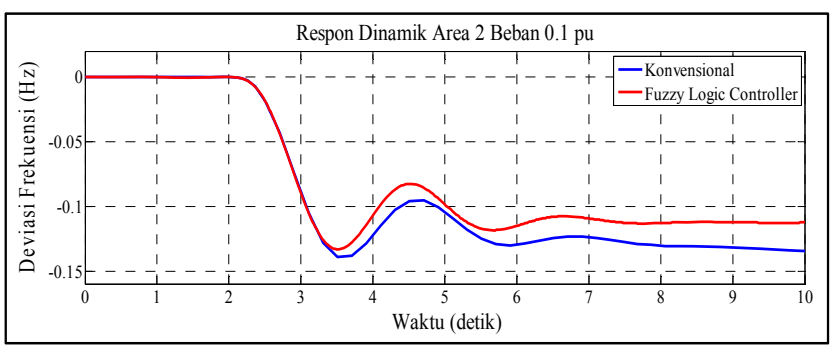

(a)

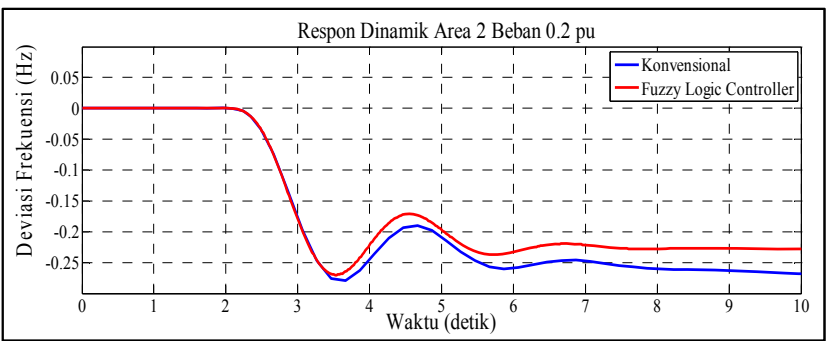

(b) 


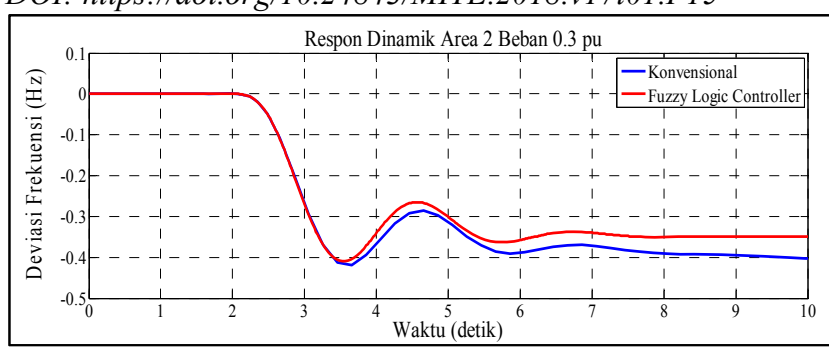

(c)

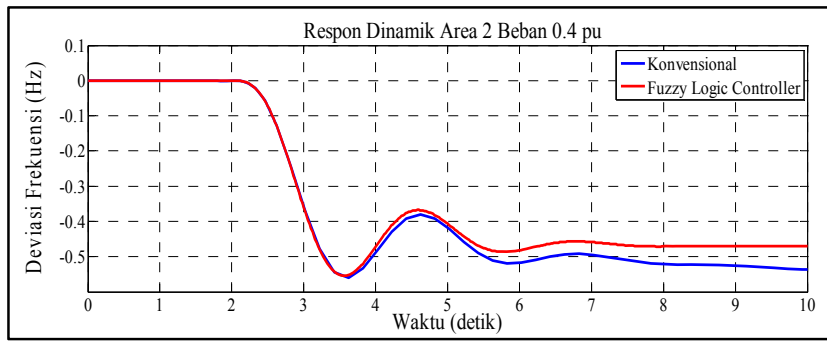

(d)

Gambar 18: Perbandingan respon dinamik load frequency control area 2 dengan beban (a) $0.1 \mathrm{pu}$ (b) $0.2 \mathrm{pu}$ (c) $0.3 \mathrm{pu}$ (d) $0.4 \mathrm{pu}$

Berdarkan perbandingan hasil simulasi yang ditampilkan pada gambar 18 dapat diperoleh perbadingan respon dinamik load frequency control area 2 yang dapat dilihat pada Tabel VIII.

TABEL VIII

PERBANDINGAN RESPON DINAMIK LOAD FREQUENCY CONTROL PADA AREA 2

\begin{tabular}{|c|c|c|c|c|c|c|c|c|}
\hline & \multicolumn{2}{|c|}{$0.1 \mathrm{pu}$} & \multicolumn{2}{|c|}{$0.2 \mathrm{pu}$} & \multicolumn{2}{|c|}{$0.3 \mathrm{pu}$} & \multicolumn{2}{|c|}{$0.4 \mathrm{pu}$} \\
\hline & PI & FLC & PI & LFC & PI & LFC & PI & LFC \\
\hline $\begin{array}{l}\text { Peak time } \\
\quad(T p)\end{array}$ & $\begin{array}{c}3.5 \\
\text { detik }\end{array}$ & $\begin{array}{c}3.5 \\
\text { detik }\end{array}$ & $\begin{array}{c}3.6 \\
\text { detik }\end{array}$ & $\begin{array}{c}3.5 \\
\text { detik }\end{array}$ & $\begin{array}{c}3.6 \\
\text { detik }\end{array}$ & $\begin{array}{c}3.5 \\
\text { detik }\end{array}$ & $\begin{array}{c}3.6 \\
\text { detik }\end{array}$ & $\begin{array}{c}3.5 \\
\text { detik }\end{array}$ \\
\hline $\begin{array}{c}\text { Settling } \\
\text { time (Ts) }\end{array}$ & $\stackrel{9}{\text { detik }}$ & $\begin{array}{c}7.1 \\
\text { detik }\end{array}$ & $\stackrel{9}{\text { detik }}$ & $\begin{array}{c}7.1 \\
\text { detik }\end{array}$ & $\begin{array}{c}9 \\
\text { detik }\end{array}$ & $\begin{array}{c}7.1 \\
\text { detik }\end{array}$ & $\stackrel{9}{\text { detik }}$ & $\begin{array}{c}7.1 \\
\text { detik }\end{array}$ \\
\hline $\begin{array}{l}\text { Deviasi } \\
\text { frekuensi } \\
\text { overshoot }\end{array}$ & $\begin{array}{c}-0.13 \\
\mathrm{~Hz}\end{array}$ & $\begin{array}{c}-0.13 \\
\mathrm{~Hz}\end{array}$ & $\begin{array}{c}-0.27 \\
\mathrm{~Hz}\end{array}$ & $\begin{array}{c}-0.27 \\
\mathrm{~Hz}\end{array}$ & $\begin{array}{c}-0.41 \\
\mathrm{~Hz}\end{array}$ & $\begin{array}{c}-0.40 \\
\mathrm{~Hz}\end{array}$ & $\begin{array}{c}-0.56 \\
\mathrm{~Hz}\end{array}$ & $\begin{array}{c}-0.55 \\
\mathrm{~Hz}\end{array}$ \\
\hline $\begin{array}{c}\text { Deviasi } \\
\text { frekuensi } \\
\text { steady state }\end{array}$ & $\begin{array}{c}-0.14 \\
\mathrm{~Hz}\end{array}$ & $\begin{array}{c}-0.11 \\
\mathrm{~Hz}\end{array}$ & $\begin{array}{c}-0.27 \\
\mathrm{~Hz}\end{array}$ & $\begin{array}{c}-0.22 \\
\mathrm{~Hz}\end{array}$ & $\begin{array}{c}-0.41 \\
\mathrm{~Hz}\end{array}$ & $\begin{array}{c}-0.34 \\
\mathrm{~Hz}\end{array}$ & $\begin{array}{c}-0.55 \\
\mathrm{~Hz}\end{array}$ & $\begin{array}{c}-0.47 \\
\mathrm{~Hz}\end{array}$ \\
\hline $\begin{array}{l}\text { Frekuensi } \\
\text { overshoot }\end{array}$ & $\begin{array}{c}49.87 \\
\mathrm{~Hz}\end{array}$ & $\begin{array}{c}49.87 \\
\mathrm{~Hz}\end{array}$ & $\begin{array}{c}49.73 \\
\mathrm{~Hz}\end{array}$ & $\begin{array}{c}49.73 \\
\mathrm{~Hz}\end{array}$ & $\begin{array}{c}49.59 \\
\mathrm{~Hz}\end{array}$ & $\begin{array}{c}49.60 \\
\mathrm{~Hz}\end{array}$ & $\begin{array}{c}49.44 \\
\mathrm{~Hz}\end{array}$ & $\begin{array}{c}49.45 \\
\mathrm{~Hz}\end{array}$ \\
\hline $\begin{array}{l}\text { Frekuensi } \\
\text { steady state }\end{array}$ & $\begin{array}{c}49.86 \\
\mathrm{~Hz}\end{array}$ & $\begin{array}{c}49.89 \\
\mathrm{~Hz}\end{array}$ & $\begin{array}{c}49.73 \\
\mathrm{~Hz}\end{array}$ & $\begin{array}{c}49.78 \\
\mathrm{~Hz}\end{array}$ & $\begin{array}{c}49.59 \\
\mathrm{~Hz}\end{array}$ & $\begin{array}{c}49.66 \\
\mathrm{~Hz}\end{array}$ & $\begin{array}{c}49.45 \\
\mathrm{~Hz}\end{array}$ & $\begin{array}{c}49.53 \\
\mathrm{~Hz}\end{array}$ \\
\hline $\begin{array}{c}\text { \%error } \\
\text { steady state }\end{array}$ & $\begin{array}{c}0.28 \\
\%\end{array}$ & $\begin{array}{c}0.22 \\
\%\end{array}$ & $\begin{array}{c}0.54 \\
\%\end{array}$ & $\begin{array}{c}0.44 \\
\%\end{array}$ & $\begin{array}{c}0.82 \\
\%\end{array}$ & $\begin{array}{c}0.68 \\
\%\end{array}$ & $\begin{array}{r}1.1 \\
\%\end{array}$ & $\begin{array}{l}1.1 \\
\%\end{array}$ \\
\hline
\end{tabular}

Berdasarkan perbandingan yang ditunjukan pada tabel VIII dapat dilihat bahwa governor sebagai load frequency control menggunakan fuzzy logic controller menghasilkan output respon frekuensi yang lebih baik dan persentase error steady state yang lebih kecil serta waktu kestabilan yang lebih cepat dibandingkan menggunakan metode PI kontroller. Hal ini diperoleh karena metode konvensional dengan PI kontroler pengaturannya yang lebih tetap sedangkan menggunakan fuzzy logic controller pengaturannya cenderung meminimalkan overshoot dan kecenderungan ini dapat memperhalus operasi sistem dan menghasilkan output respon frekuensi dinamik yang lebih baik.

\section{KESIMPULAN}

Governor sebagai load frequency control dengan mengunakan kedua metode yaitu metode PI kontroller dan fuzzy logic controller menghasilkan output respon frekuensi dinamik yang masih sesuai dengan standar yang diijinkan yaitu $50 \pm 2 \%$, ini berarti sistem bekerja masih pada range frekuensi $49 \mathrm{~Hz}$ sampai dengan $51 \mathrm{~Hz}$. Governor sebagai load frequency control menggunakanan fuzzy logic controller menghasilkan output respon frekuensi dinamik yang lebih baik dan persentase error steady state yang lebih kecil serta waktu yang dibutuhkan untuk mencapai keadaan steady state yang lebih cepat dibandingkan menggunakan metode PI kontroller.

\section{REFERENSI}

[1] Robandi, I. Desain System Tenaga Modern. Yogyakarta: Penerbit Andi. 2006

[2] Menteri Energi dan Sumber Daya Mineral. 2007. Aturan Jaringan Sistem Tenaga Listrik Jawa-Madura-Bali. Jakarta: Departemen Energi dan Sumber Daya Mineral.

[3] Kusumadewi, S. Artificial Intelligence (Teknik dan Aplikasinya). Yogyakarta: Graha Ilmu. 2003.

[4] Patriandari. "Analisis Pengoperasian Speed Droop Governor sebagai Pengaturan Frekuensi pada Sistem Kelistrikan PLTU Gresik". Digilib ITS Undergraduate. 2009.

[5] Saadat, H. Power System Control. London: Imperial Press. 1999.

[6] Armada, I. N. A., Suweden, I. N., Amrita, A. A. N. "Studi Analisis Governor sebagai Load Frequency Control pada PLTG 2x42,5 MW PT. Indonesia Power UBP Bali”. E-Journal Spektrum, Vol 5 No 6. 2013.

[7] Meilandari, E. D., Hartati, R. S., Sukerayasa, I. W. "Analisa Aliran Daya Optimal pada Sistem Kelistrikan Bali”. Teknologi Elektro, Vol 11 No 1 (Januari-Juni): 36-40. 2012.

[8] Mataram, I. M. "Unjuk Kerja Fuzzy Logic Static Syncronous Compensator (FLSTATCOM) untuk Meningkatkan Tegangan Sistem". Teknologi Elektro, Vol 15 No 1 (Januari-Juni) : 34-37. 2016.

[9] Naba, A. Belajar Cepat Fuzzy Logic Menggunakan Matlab. Yogyakarta: ANDI Yogyakarta. 2009.

[10] Zhang, Y. "Load Frequency Control of Multiple-Area Power System," M. Eng. thesis, Cleveland State University, Ohio, United States, August. 2009

Gusti Made Ngurah Christy Aryanata: Studi Analisis Governor sebagai... 